\title{
THE "HESYCASTIC" MANDORLA: APOPHATIC ART AND HESYCHAST THEOLOGY
}

\author{
Nichifor TĂNASE*
}

\begin{abstract}
In this study we will try to present the iconographic tradition as a form of visual theology, though it is difficult to conceptualize what it like to be in the immediate presence of God. The Transfiguration is one of the keys that can unlock the mystery of our eschatological fate, glorified body and the participation in the energies of God. All the ascetics who had the experience of the uncreated light or were transfigured themselves describe it in very similar way and connect it with the Transfiguration of Christ. It is only in later hesychasm that we are assured theologically that these experiences were in the body. Within this context, liturgical art and aesthetics differ from secular aesthetics, as being beyond the five senses and beyond the art itself. The Fathers, from Origen to John of Damascus, refer to Christ as the visible image and consubstantial icon of the Father. Icons were anything more than vessels of the grace of God and suggest the real presence of the grace of the depicted person. In the Old Testament, God denied the wish of anyone who asked to see him directly. The desire to see God was impossible before the Incarnation of Christ. The mosaic of the Transfiguration in St Catherine Monastery on Mount Sinai shows a completely glorified Christ with eight rays emanating from his body and introduces the luminous mandorla, a symbol that symbolizes the glory of God. The mandorla of the Sinai mosaic is oval, whereas the mandorla of the Rabbula Gospels is round. These two types express the glory of God in different way, highlighting the correspondence between theological concepts and the visual language. Mandorla expresses visually the Jewish concept of kabod, that connoted a more physical, concrete presence than the abstract meaning of $\delta$ ó $\xi \alpha$. Certain scholars separate two main meanings of kabod: shekinah (from shakan, "to live in a tent" or simply "to dwell") and yeqara (from yqr, the
\end{abstract}

* PhD, Lecturer, Eftimie Murgu University (Department of Theology and Social Sciences), Reșița, Romania. 
sensory splendor of light), in order to express this visual manifestation of the two natures of Christ. So, the oval mandorla corresponds with the luminous characterists of the kabod as yeqara. Here, the three concentric oval layers, increasingly dark, represent the depiction of the excessive divine light as the darkness of the incognoscibility of God, even in revelation. The round mandorla, on the other hand, represents the manifestation of the kabod-glory of God as shekinah/tabernacle. Here, the emphasis on the spatial rather than luminous nature of mandorla described the glimpse of the Trinity, as opposed to a less-historicized reading that emphasized the continuous splendor of Christ. The Transfiguration enjoyed a renewed interest in fourteenth-century theology, and, at the same time, a mysterious complex mandorla made its appearance, the socalled "hesychastic" mandorla (first appears in the churches of Mistras and in manuscripts of the ex-emperor and hesychastic monk, John Cantacuzenos). It consists of a geometric design as two superimposed concave squares (actually a square and a rhombus) inside a circle. These three shapes circle-square-rhombus superimposed on top of each other indicate the Trinity. This ties with Gregory Palamas's attempt to harmonize the days of the Gospel narratives: "six" (six figures who are visible) and "eight" (adds the two who were invisible but certainly present, the Father and the Holy Spirit). Therefore, in our study we analyze how the icon of the Transfiguration encapsulates the ascetic ascent to deification.

Keywords: mandorla, apophaticism, hesychasm, divine light, deification

\section{Corporality and Immateriality (asomata graphê)}

The first fundamental criterion of iconoclast theology and Christology is the distance they place between icon and person, secondly their refusal to accept any kind of hypostatic pictorial representation, and thirdly their final inability to reconcile "pictorial representation" (eikonizesthai ) with "hypostatisation" or real existence (hyphestanai )1.

1 Ambrosios Giakalis, Images of the Divine. The Theology of Icons at the Seventh Ecumenical Council, revised edition, with a Foreword by Henry Chadwick, Leiden/Boston, Brill, 2005, p. 99. The bodies of Christ and the saints are described by the iconoclastss as 'not present' (me paronta). Giakalis mentions also the problem of the iconoclastic understanding of the Eucharist as an icon of Christ. He quotes B.N. Giannopoulos who argues that for the iconoclasts the bread of the Eucharist is not the 
As Henry Maguire has argued, the iconoclast debate and the victory of the iconodules resulted in a new definition of the role and function of icons:

"As a result of the debate over images, there was less ambiguity after iconoclasm concerning their status. Christian icons were seen as intermediaries between the suppliant and the invisible power rather than as powers in themselves. In theory it was no longer possible for icons of the saints to have the ability to act on their own; icons could only facilitate access to the prototypes in the hope of their intercession with the supreme Judge." 2

It was made clear that veneration was due to icons because of their representations, not because of their inherent supranatural powers. According to Brown, the iconoclastic controversy was instead essentially a dilemma over the position of the holy in the Byzantine world ${ }^{3}$. The need to define and to name that differentiates post-iconoclastic Byzantine portraiture from earlier practice is apparent in every medium and type of object. The post-iconoclastic concept of the functioning of images had important consequences for the design and presentation of the portraits of the saints ${ }^{4}$. The importance of intercession in the functioning of icons is emphasized in many post-iconoclastic saints' lives ${ }^{5}$. From the time of the early desert fathers, monks had been compared to the bodiless angels, the asomata $^{6}$.

body of Christ, nor an icon or type of Christ himself because the divine nature and hypostasis are undepictable. Another scholar who cites is S. Gero, who, on the other hand, asserts the consubstantiality of the divine Eucharist and the flesh of Christ. See, S. GERO, "The Eucharistic Doctrine of the Byzantine Iconoclasts", in Byzantinische Zeitschrift, no. 68/1975, p. 4-22, here p. 9.

${ }^{2}$ Henry Maguire, The Icons of their Bodies: Saints and their Images in Byzantium, Princeton, New Jersey, Princeton University Press, 1996, p. 138.

3 Peter Brown, Society and the Holy in Late Antiquity, Berkeley, Los Angeles and London, University of California Press, 1989, p. 103-152.

${ }^{4}$ Warren T. Woodfin, The Embodied Icon: Liturgical Vestments and Sacramental Power in Byzantium, Oxford, Oxford University Press, 2012, p. 103-132.

5 Liz JAMES, "Seeing's believing, but feeling's the truth': Touch and the Meaning of Byzantine Art", in Angeliki Lymberopoulou (ed.), Images of the Byzantine World. Visions, Messages and Meanings. Studies Presented to Leslie Brubaker, Farnham, UK, Ashgate, 2011, p. 1-14.

${ }^{6}$ H. Maguire, op. cit., p. 67. See, also: E. Kitzinger, "The Cult of Images in the Age 
After the complete victory over the paganism, there was not much need for philosophical or secular wisdom, contemplation and prayer are replacing the intellectual interest. Iconoclasm changed the situation, because to be defenders of icons, the monts had to turn to philosophy and the study of the fathers and to construct intellectual arguments to refute the accusation of the iconoclasts. Therefore, education and study found a new place and purpose within monastic activities. The relationship between painting and eloquence had been a familiar theme of ancient rhetoric that the fourth-century Fathers of the Greek Church applied to Christian contexts. Byzantine authors made numerous references to the connections between verbal eloquence and the visual arts ${ }^{7}$. Thus the relationship between art and eloquence became an important concept in the arsenal of the defenders of images during the iconoclastic controversy.

"The usefulness of art as a means of instruction was only one of the arguments in favor of Christian images that John of Damascus derived from the relationship between writing and painting. He also exploited the multiple meanings in the term eikōn, which, like the English word 'image', could mean both a concrete representation, as in a painting, and a conceptual representation, such as might be created in writing". 8

before Iconoclasm", in Dumbarton Oaks Papers, no. 8/1954, p. 81-150; E. KITZINGER, The Art of Byzantium and the Medieval West, Bloomington, Indiana University Press, 1976; H. MAGUiRE, "Disembodiment and Corporality in Byzantine Images of the Saints", in B. CASSIDY (ed.), Iconography at the Crossroads, Princeton, 1993, p. 7583; A. CAMERON, "The Language of Images: The Rise of Icons and Christian Representation", in D. WooD (ed.), The Church and the Arts, Oxford, 1992, p. 1-42; L. BRUBAKER, "Byzantine Art in the Ninth Century: Theory, Practice, and Culture", in Byzantine and Modern Greek Studies, no. 13/1989, p. 23-93; "Perception and Conception: Art, Theory and Culture in Ninth-century Byzantium", in Word and Image, no. 5/1989, p. 19-32; G. DAGRON, "Holy Images and Likeness", in Dumbarton Oaks Papers, no. 45/1991, p. 23-33.

${ }^{7}$ John MONFASANI, George of Trebizond; A Biography and a Study of His Rhetoric and Logic, Leiden, Brill, 1976, p. 248-255. The Greek language itself encouraged the Byzantines to think in these terms. The word graphe, for example, was used for both writing and painting, historia could mean either a written history or a picture, whereas schēma was both a figure of rhetoric and a pose in painting. Leslie Brubaker, "Image, meta-text and text in Byzantium", in S. SATO (ed.), Herméneutique du text d'histoire: orientation, interprétation et questions nouvelles, Tokyo, Nagoya University, 2009, p. 93-100.

${ }^{8}$ Henry Maguire, Art and Eloquence in Byzantium, Princeton, New Jersey, Princeton 


\section{Kabod (Glory of God) and Oval Mandorla with Rays. The Sixth-Century Mosaic of the Transfiguration in St. Catherine Monastery on Sinai}

a) Shekinah and the round mandorla. The mandorla could be mistaken for the cloud as the glory of God. But, the cloud enters the narrative after the change itself, as a separate element. The voice of the Father reveals his filial relationship with Christ, expression of "the hypostatical definition rather then unity of essence" ${ }^{\text {. Godhead is revealed }}$ in the glory of the Christ. Origen and Anastasios the Sinaite say that Moses and Elijah were also transfigured in glory. The spatial rather than the luminous nature of mandorla is more appropriate for a narrative reading, which describes "the manifestation of the glory of God, a glimpse of the Trinity, as opposed to the continous splendor of Christ"10.

According to the Gopsel narratives as well as several Fathers, the luminous cloud enveloped not only the prophets but also the apostles. This suggestes that the round mandorla does not signify the luminous cloud; rather, it is a symbolic rendering of the glory of God as a tabernacle/shekinah. Unprepeared who could not endure the divine light, remained outside the tabernacle of God. They are granted the vision by the divine grace only. The round mandorla appeared for the first time in the Rabbula Gospels Transfiguration in the sixth century and was found quite commonly in Transfiguration depistions until the eleventh century,

University Press, 1994, p. 10. He also points out the antithesis in Byzantine art and literature (e.g., juxtaposition of the Virgin and Child with the Dormition): "In the Byzantine church, antithesis was more than a figure of speech; it was a habit of thought. This stylistic device, common both to antique rhetoric and to the literature of the Bible, provided Christian writers with a ready-made mould in which to cast the paradoxes of their faith. The Fathers of the Greek church made liberal use of antithesis in order to express the paradoxical nature of Christ's incarnation, for it enabled them to clothe unfamiliar mysteries in a linguistic convention that pagan education had made familiar to their audiences" (MAGUIRE, Art and Eloquence, p. 53). He has moved the study of Byzantine art in new directions, revealing a vista of complexity and variation. See, also, H. MAguire, Nectar and Illusion: Nature in Byzantine Art and Literature, Oxford, Oxford University Press, 2012, p. 48-77.

9 Andreas Andreopoulos, Metamorphosis. The Transfiguration in Byzantine Theology and Iconography, Crestwood, New York, St Vladimir's Seminary Press, 2005, p. 98.

${ }^{10}$ Ibidem, p. 96. 
as a way to portay the glory of God. The round mandorla is an expression of the place where God is, and it corresponds very closely to the concept of shekinah.

The word shekinah, says Andreopoulos, expressed "a physical manifestation of God within history, a revelation and a dwelling and a

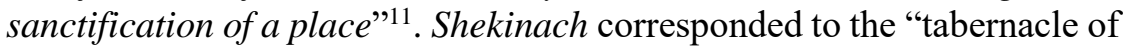
God" in the physical world and was connected with the messianic enthronement.

b) Yeqara and the oval mandorla with rays. The oval mandorla corresponds with the luminous characteristics of the kabod (glory).

"Drawn around the body of Christ in a way that represents a luminance and not a space, it is consistent with the understanting of kabod as yeqara and also with the Johannine and patristic identification of Christ as light or, specifically to the Transfiguration, as the glory of the Father."12

The oval mandorla that envelops the transfigured Sinaitic image of Christ - the prototype for the oval mandorla type in general - consists of three concentric oval layers, increasingly dark they approach the center. The metaphorical darkness or blindness caused by excessive luminosity. The excessive radiance reflects the patristic strand of the theology of darkness (Philo, Gregory of Nyssa, pseudo-Dionysios). More importantly, in relation to the oval mandorla, all who expounded the theology of light in terms of the ascent of Moses ended this ascent in divine darkness.

"The Sinai Mandorla, different from the circular luminous mandorla more frequently used until the eleventh century, expresses the culmination of the ascetic ascent in the most mystical representation of the time - the depiction of the excessive divine light as the darkness of the incognoscibility of God, even in his revelation."13

The layered oval mandorla with rays, which could not be confused with the luminous cloud, was a more appropriate symbol to express the mystical "non-narrative" light of Christ. The second constituent meaning of the glory of God, yeqara, which Hans Urs von Balthasar read as an

\footnotetext{
11 Ibidem, p. 88.

12 Ibidem, p. 90.

${ }^{13}$ Ibidem, p. 91.
} 
expression of the sensory experience of light is "the resplendent glory which reveals and hides God at the same time, similar to the spiritual brightness"14. It is appropriate only to the person to whom the glory belongs and cannot be extended to cover beholders, because it does not constitute a holy space with the characteristics of a tabernacle, as was the case with shekinah. In conclusion, highlights Andreopoulos, in contrast to later depiction of the Transfiguration, the Sinai mosaic shows the apostle very close to Christ and the prophets, something that suggests theosis is possible ${ }^{15}$.

\section{Icons and the Theology of Light (malicious juxtaposition Palamites - iconoclasts)}

Hesychasm is a monastic tradition of contemplative prayer that began roughly in the early fifth century on Mount Sinai. Hesychastic contemplation was sometimes accompanied by visions of the divine light. This connected it naturally with the tradition of the theology of light from the writings of the Fathers such as Gregory of Nazianzus, Evagrius of Pontus, Ps-Makarios, Diadochos of Photiki, Mark the Ascetic, Isaac the Syrian, John of the Lader, Maximos the Confessor and Gregory the Sinaite ${ }^{16}$. The light is the main conceptual and theological focus of all the themes syntesis: Transfiguration as a theophaniy and as a revelation of the inner life of God, this visual manifestation of the two nature of Christ, the usual patristic view that the body of Christ was glorified by the glory of his divinity. The icon of the Transfiguration was the best possible iconographic portrayal of the two natures of Christ.

The juxtaposition Palamites - iconoclasts, allow Gregoras to transpose the whole $9^{\text {th }} \mathrm{c}$. ideological situation (as he understood it) into the 14th $\mathrm{c}$. and make it seem uptodate and actual.

"If Hesychasm in Gregoras' interpretation was no more than a renovated iconoclasm in combination with other heresies of old times, if Palamas was a heretic par excellence (new Arius, Eunomius, and

${ }^{14}$ Ibidem, p. 88.

15 Ibidem, p. 138.

16 John Anthony McGuckin, Standing in God's Holy Fire: The Byzantine Tradition, Mayknoll, New York, Orbis Books, 2001, p. 109-130. 
Eusebius), Gregoras himself would naturally become a new confessor Theodoros Graptos, and Ioannes Kantakouzenos - a new impious tyrant Theophilos. It seems highly probable that Gregoras did have this picture in mind". ${ }^{17}$

Nikephoros' testimonies were employed by both parties to prove that their opponents were guilty of iconoclasm. Gregoras became the first to lay an accusation of iconoclasm (iconoclastic theology of the Tabor light). Philotheos Kokkinos after having quoted Gregoras citing Nikephoros begins refutation in the $11^{\text {th }}$ Oration against Nikephoros Gregoras, where he even confessed that the teaching of Gregoras and Akindynos matches in many ways that of Arians and iconoclasts (Ioannes Italos was guilty of iconoclasm). Lukhovitskij conclusion is that the accusation of iconoclasm originated within the antiPalamite circles and at least on the first stages of the controversy it were antiPalamites who attacked and Palamites who were forced to defend. V. Lourié expressed an opposite view: antiPalamites were hostile to sacred images since their teaching inevitably deprived God's energies of the ability to be actually present in the icon, thus, Palamites actually revealed their enemies' hidden iconoclasm ${ }^{18}$. Therefore, "as soon as the partisans of icon veneration (Ioannes Damaskenos, Nikephoros of Constantinople, Theodoros Stoudites etc.) and their spiritual heirs (Photios of Constantinople) established an inextricable theological link between iconoclasm and earlier Christological heresies, a charge of iconoclasm became equal to an accusation of all these previous blasphemies taken together (Arianism, Nestorianism, Docetism, etc.)"19. Barlaam became the first to recognize the fundamental distinction between the Augustinian theology of the divine essence and the hesychasts' theology of the

${ }^{17}$ Lev LuKHOVITSKIJ, "Historical Memory of Byzantine Iconoclasm in the 14th c.: the Case of Nikephoros Gregoras and Philotheos Kokkinos", in Sergei MARIEV and Wiebke-Marie Sтоск (eds.), Aesthetics and Theurgy in Byzantium, Boston/Berlin, Göttingen, Walter de Gruyter Inc., 2013, p. 205-230, here p. 224. This clearly stated typological principle allows Gregoras to use antiarian, antieunomian and antiiconoclastic sources to refute what he calls "Palamite heresy". For the obsession with the $9^{\text {th }} \mathrm{c}$. during the Hesychast controversy on the iconographic level, see D. Kotoula, "The British Museum Triumph of Orthodoxy Icon", in A. Louth and A. CAsiday, Byzantine Orthodoxies, Aldershot, 2006, p. 121-130.

${ }^{18}$ LuKHOVITSKIJ, op. cit., p. 216.

${ }^{19}$ Ibidem, p. 205. 
uncreated light. The light beheld by the hesychasts is identified by Palamas with the light that shone around Christ at the Transfiguration. It is not a created symbol, but the "garment of their deification" and a foretaste of the light that will eternally illuminate the blessed (Triads i.3.5, $26)^{20}$. As shown by David Bradshaw, it is in searching for a term suitable for referring both to the light of the Transfiguration and to the "things around God" that Palamas introduces the concept of energeia. "Palamas thus draws together under the single concept of energeia a number of themes that previously had existed more or less in isolation: the uncreated light, the 'things around God', the Cappadocian teaching on the divine names, and the Pauline and Cappadocian understanding of the indwelling of the Holy Spirit"21. Through the energies of God, we know the beauty and splendour of God. Anita Strezova says that Palamas instigated a 'new Christocentric humanism' founded on the hesychast concepts of theosis, synergia and theologia. "This approach to the issue of experience of God implied the basic anthropological presupposition that man was capable of transcending his own nature, as well as the main theological principle that God - even when he communicates himself - remains transcendent" ${ }^{\text {"22 }}$. In terms of symbolism, important novelties were the introduction of complex mandorla, the appearance of eight rays of light, the appearance of the 'O $\Omega \mathrm{N}$ ('I am who I am') monogram on the halo of Christ, and the introduction of three-dimensional rainbows ${ }^{23}$.

20 Gregory Palamas, The Triads, edited with an Introduction by John Meyendorff Translation by Nicholas Gendle, preface by Jaroslav Pelikan, Mahwah, New Jersey, Paulist Press, 1983 [hereinafter: Tr.], p. 33. The light is in fact the eternal and uncreated glory of God: "God, while remaining entirely in Himself, dwells entirely in us by His superessential power, and communicates to us not His nature but His proper glory and splendour" (Tr. i.3.23, p. 39).

21 David Bradshaw, Aristotle East and West Metaphysics and the Division of Christendom, Cambridge, Cambridge University Press, 2004, p. 237-238.

${ }^{22}$ Anita Strezova, Hesychasm and Art: The Appearance of New Iconographic Trends in Byzantine and Slavic Lands in the 14th and 15th Centuries, Canberra, Australia, The Australian National University Press, 2014, p. 51, 62.

${ }^{23}$ STREZOVA, op. cit., p. 73-75. The painted surfaces were illuminated with white strokes (on the face, neck and hands) representing the rays of the divine light. Also, the image of Theotokos (the Mother of God) the Life-Giving Spring appeared in the 14th century. Thus, the Akathist Hymn at the Trinity Church, Cosia, symbolises Palamas's concepts regarding the role of the Virgin in the history of salvation. She is endorsed with a complex mandorla that is commonly reserved for Christ (this also testifies the role of 
The icon of the Transfiguration was the best way to traslate into imagery the hesychastic views on the uncreated light. The apostle are more thn mere witnesses to the event, they dynamically perceive the glory of Christ. Moreover, the representation of the mountain is almost personalized and it has to do with the significance of the ascetic ascent. The "hesychastic" mandorla appears in the fourteenth-century churches of Mistra and in an illumination from the manuscript of the emperormonk John (Ioasaph) VI Kantakouzenos. This magnificent mandorla, with or without rays consists of two superimposed concave squares actually a square and a rhombus - inside a circle. Andreas Andreopoulas identified the Transfiguration as a revelation of the Trinity:

"It is possible, though, that Orthodox iconography wanted to represent the Father alone as the circle that has no beginning or end, and the two others hypostases as rectangles, in order to express the Eastern reaction to the Western addition of the filioque to the Nicene Creed."24

Moreover, the precise positioning of Christ in the circle reminds us of Christ's words "I am in the Father, and the Father is in me" (Jn. 14, 10). Theophanes the Greek follow and completes the Byzantine hesychastic type by some detailes that refer to hesychastic theology directly, such as the rays of light and the unsusual illumination of Moses, Elijah and the three apostles. The two interpenetrating triangles expresses the downward movement of the Incarnation and revelation of the divinity of Christ to humanity, combined with the upward movement of the ascetic ascent, the doctrine of the divine and human synergy. Thi unique mandorla gives a sense of spiritual escalation through light to Christ, who is the source of light. Theophanes dis something revolutionary to indicate Christ as the source of light,

"The body of Elijeh, Moses, and the three apostles are illuminated not only from the inside, as in customary in Byzantine iconography, but also from the ouside in a way that indicates Christ as the sources of the physical light. This is highly unusual. Byzantine iconography never

Theotokos in salvation, a representative of those who acquired true vision of light). According to the teaching of St Gregory Palamas, she has, in fact, brought the light into the world.

${ }^{24}$ ANDREOPOUlOS, op. cit., p. 231. 
indicates any sources of the external light". ${ }^{25}$

The rays emitting from Christ and reaching the apostles are intentionally asymmetrical and end at the faces of Peter, John and James. Theophanes here indicates that the rays symbolize: 1. the uncreated energies of God, 2. the grace that was given to the three apostle from Christ, 3. The operation of the Holy Spirit that allowed them to see Christ in his divinity. The rays end not merely on the faces, but specifically on the eyes of the apostle. Thus, covered with the beauty of ineffable glory of the Spirit, apostles "becomes all light, all face, all eye" because there is no part of the soul that is not full of the spiritual eyes of light.

The theological justification then, of the correct approach to the veneration of icons is found ultimately in the teaching of the Eastern Fathers on deification" ${ }^{27}$. This "perception" of the participation of the icons in the uncreated, purifying and sanctifying energy of God is so intense that the only way out is through worship, that is, through actually turning toward $\operatorname{God}^{28}$.

\section{Conclusion: The Byzantine "esthetics of Apophaticism".}

The iconophile veneration of icons may be summarised as follows: The uncreated God imparts himself to his creatures in his uncreated glory or energies. Only the saints and the angels participate in the deifying energies of God. The illuminating energies are also participated in through the icon by virtue of the icon's hypostatic identity with its

${ }^{25}$ Ibidem, p. 247.

${ }^{26}$ Pseudo-MACARIUS, The Fifty Spiritual Homilies and the Great Letter, translated, edited and with an introduction By George A. Maloney, S.J., Preface By Kallistos Ware, New York, Mahwah, Paulist Press, 1992, p. 31.

${ }^{27}$ Leonidas ConTos, The Concept of Theosis in Gregory Palamas, with a critical text of the 'Contra Akindynum', 2 vols., Los Angeles 1963. See, also: Alexis TorRANCE, „Precedents for Palamas' Essence-Energies Theology in the Cappadocian Fathers”, in Vigiliae Christianae, no. 63/2009, p. 47-70 and A.N. WiLliams, The Ground of Union: Deification in Aquinas and Palamas, Oxford, Oxford University Press, 1999.

${ }^{28}$ Paul Evdokimov, The Art of the Icon: a Theology of Beauty, Redondo Beach, CA: Oakwood, Publications, 1972. Leonid OusPENSKY, Theology of the Icon, Crestwood, NY, St. Vladimir's Seminary Press, 1978. Michel QuENOt, The Icon: Window on the Kingdom, Crestwood, NY, St. Vladimir's Seminary Press, 1991. 
prototype. Contact/veneration with the icon/vehicle of these divine energies communicates the latter to the venerator himself in proportion to his spiritual state. Denial of the possibility of participation in divine energies by means of the veneration of the icons means the rejection of the Church's doctrine on the deification of human nature.

\section{References:}

1. ANDREOPOUlos, Andreas, Metamorphosis. The Transfiguration in Byzantine Theology and Iconography, Crestwood, New York, St. Vladimir's Seminary Press, 2005.

2. Bradshaw, David, Aristotle East and West: Metaphysics and the Division of Christendom, Cambridge, Cambridge University Press, 2004.

3. Brown, Peter, Society and the Holy in Late Antiquity, Berkeley, Los Angeles and London, University of California Press, 1989.

4. BRUBAKeR, Leslie, "Byzantine Art in the Ninth Century: Theory, Practice, and Culture", in Byzantine and Modern Greek Studies, no. 13/1989, p. 23-93;

5. BRUBAKER, Leslie, "Image, meta-text and text in Byzantium", in S. Sato (ed.), Herméneutique du text d'histoire: orientation, interprétation et questions nouvelles, Tokyo, Nagoya University, 2009, p. 93-100.

6. BRUBAKER, Leslie, "Perception and Conception: Art, Theory and Culture in Ninth-century Byzantium", in Word and Image, no. 5/1989, p. 19-32;

7. CAMERON Averil, "The Language of Images: The Rise of Icons and Christian Representation", in D. WoOD (ed.), The Church and the Arts, Oxford, 1992, p. 1-42;

8. Contos Leonidas, The Concept of Theosis in Gregory Palamas, with a critical text of the 'Contra Akindynum', 2 vols., Los Angeles 1963.

9. DAGRon, Gilbert, "Holy Images and Likeness", in Dumbarton Oaks Papers, no. 45/1991, p. 23-33.

10. Evdokimov, Paul, The Art of the Icon: a Theology of Beauty, Redondo Beach, CA: Oakwood, Publications, 1972.

11. Gero, Stephen, "The Eucharistic Doctrine of the Byzantine Iconoclasts", in Byzantinische Zeitschrift, no. 68/1975, p. 4-22.

12. GiaKalis Ambrosios, Images of the Divine. The Theology of Icons at 
the Seventh Ecumenical Council, revised edition, with a Foreword by Henry Chadwick, Leiden/Boston, Brill, 2005.

13. JAMES, Liz, 'Seeing's believing, but feeling's the truth': Touch and the Meaning of Byzantine Art", in Angeliki Lymberopoulou (ed.), Images of the Byzantine World. Visions, Messages and Meanings. Studies Presented to Leslie Brubaker, Farnham, UK, Ashgate, 2011, p. 1-14.

14. KitZINGER, Ernst, "The Cult of Images in the Age before Iconoclasm", in Dumbarton Oaks Papers, no. 8/1954, p. 81-150.

15. KitZINGER, Ernst, The Art of Byzantium and the Medieval West, Bloomington, Indiana University Press, 1976.

16. Kotoula, Dimitra, "The British Museum Triumph of Orthodoxy Icon", in A. LOUTH and A. CASIDAY, Byzantine Orthodoxies, Aldershot, 2006, p. 121-130.

17. LUKHOVITSKIJ, Lev, "Historical Memory of Byzantine Iconoclasm in the 14th c.: the Case of Nikephoros Gregoras and Philotheos Kokkinos", in Sergei MARIEV and Wiebke-Marie StOcK (eds.), Aesthetics and Theurgy in Byzantium, Boston/Berlin, Göttingen, Walter de Gruyter Inc., 2013, p. 205-230.

18. MaguiRe, Henry, "Disembodiment and Corporality in Byzantine Images of the Saints", in B. CASSIDY (ed.), Iconography at the Crossroads, Princeton, 1993, p. 75-83;

19. Maguire, Henry, Art and Eloquence in Byzantium, Princeton, New Jersey, Princeton University Press, 1994.

20. MaguiRe, Henry, Nectar and Illusion: Nature in Byzantine Art and Literature, Oxford, Oxford University Press, 2012.

21. MaguiRe, Henry, The Icons of their Bodies: Saints and their Images in Byzantium, Princeton, New Jersey, Princeton University Press, 1996.

22. MCGuCKIN John Anthony, Standing in God's Holy Fire: The Byzantine Tradition, Mayknoll, New York, Orbis Books, 2001.

23. Monfasani, John, George of Trebizond; A Biography and a Study of His Rhetoric and Logic, Leiden, Brill, 1976.

24. OUSPENSKY, Leonid, Theology of the Icon, Crestwood, NY, St. Vladimir's Seminary Press, 1978.

25. Palamas, Gregory, The Triads, edited with an introduction by John Meyendorff, translation by Nicholas Gendle, preface by Jaroslav Pelikan, Mahwah, New Jersey, Paulist Press, 1983

26. Pseudo-MACARIUS, The Fifty Spiritual Homilies and the Great Letter, 
translated, edited and with an introduction by George A. Maloney, S.J., Preface By Kallistos Ware, New York, Mahwah, Paulist Press, 1992.

27. QUENOt, Michel, The Icon: Window on the Kingdom, Crestwood, NY, St. Vladimir's Seminary Press, 1991.

28. Strezova, Anita, Hesychasm and Art: The Appearance of New Iconographic Trends in Byzantine and Slavic Lands in the 14th and 15th Centuries, Canberra, Australia, The Australian National University Press, 2014.

29. TORRANCE, Alexis, „Precedents for Palamas' Essence-Energies Theology in the Cappadocian Fathers", in Vigiliae Christianae, no. 63/2009, p. 47-70.

30. Williams, Anna N., The Ground of Union: Deification in Aquinas and Palamas, Oxford, Oxford University Press, 1999.

31. Woodfin, Warren T., The Embodied Icon: Liturgical Vestments and Sacramental Power in Byzantium, Oxford, Oxford University Press, 2012. 